Egyptian J. of Nutrition Vol. XXXV No. 2 (2020)

\title{
Immunomodulatory Efficacy of Phyllanthus Emblica and Costus Speciosus Aqueous Extracts for Immunosuppressive Rats.
}

\author{
El-Sayed H. Bakr ${ }^{1}$ and Mona. E.M.Naga ${ }^{2}$ \\ 1Nutrition and Food Science Department, Faculty of Home \\ Economics, Minufiya University, Egypt. \\ 2Home Economics Department, Faculty of Specific Education, \\ Minufiya University, Egypt.
}

\begin{abstract}
The immune system helps in eliminating toxic or allergenic substances that enter through mucosal surfaces. The immune system's ability to mobilize a response to an invading pathogen, toxin or allergen is its ability to distinguish self from non-self. This investigation aimed to study the immunomodulatory efficacy of phyllanthus emblica and costus speciosus aqueous extracts for immunosuppressive rats. Forty two mature male albino rats weighing 150-200 g were used in this work. Rats were divided into 6 equal groups ( $n=7$ rats); one group kept as a control negative, while the rest five groups were once injected intraperitoneally with a single dose $(200 \mathrm{mg} / \mathrm{kg}$ body weight) of cyclophosphamide for immunosupprission, then devided to five equal groups, one of them left as control positive group $(\mathrm{C}+\mathrm{ve})$ while the rest four groups orally ingested with two doses (250 and $500 \mathrm{mg} / \mathrm{kg}$ ) of phyllanthus emblica and costus speciosus aqueous extracts for each of them. At the end of experimental period (45 days), blood samples were collected and CD4, CD8, CD16 and CD19 were analyzed by flow cytometric
\end{abstract}




\section{El-Sayed H. Bakr and Mona. E.M.Naga}

analysis. $\lg \mathrm{M}, \lg \mathrm{A}$ and $\lg \mathrm{G}$ were determined using indirect enzymelinked immunosorbent assay (ELISA). The levels of serum albumin and globulin were determined. The obtained results concluded that phyllanthus emblica and costus speciosus enhanced immunomodulatory efficacy by increasing blood levels of CD4, CD8, CD16, CD19, IgM and IgG, moreover, increasing serum levels of albumin and globulins. The group of costus speciosus at a dose of $500 \mathrm{mg} / \mathrm{kg}$. b.wt., declaired the best significant results to boost immunity compared to all experimental groups. The present investigation revealed that Phyllanthus emblica and costus speciosus aqueous extracts possess immunomodulatory efficacy with regard to immunosuppressive animals.

\section{Introduction}

The immune system helps in eliminating toxic or allergenic substances that enter through mucosal surfaces. The immune system's ability to mobilize a response to an invading pathogen, toxin or allergen is its ability to distinguish self from non-self (Chaplin, 2010).

The immune system cells must be able to discriminate between non-self-molecules which are harmful (e.g., those from pathogens) and innocuous non-self-molecules (e.g., from food), accordingly, the main issue of nutrients explores the relationship among diet, nutrients and immune function (Childs et al., 2019).

Herbal medicine as an imperative branch of complementary and alternative medicine has increasingly grown in the last decades (Dai, et al., 2017). Numerous plants constituents have unique ability in modulating immune system including glycosides, polysaccharides, 
Egyptian J. of Nutrition Vol. XXXV No. 2 (2020)

alkaloids, saponins, flavonoids, sterols and sterolins (Chandra et al., 2015).

Phyllanthus emblica Linn commonly known as Indian gooseberry or Amla, is the most important medicinal plant in the Indian traditional system of medicine. Furthermore, experimental studies reported that Phyllanthus emblica Linn and its phytochemicals exhibit anticarcinogenic properties. which possess radiomodulatory, chemomodulatory, chemopreventive, free radical scavenging, antioxidant, anti-inflammatory, antimutagenic and immunomodulatory activities (Bhandari and Kamdod, 2012).

Phyllanthus emblica Linn contains phenolic compounds, phyllembelic acid, tannins, phyllembelin, rutin, emblicol and curcuminoids as antioxidants. Moreover, it is rich in tannins including (gallicaid, phyllemblis acid, elagic acid and emblicol, and a wide range of phytochemical components including alkaloids, terpenoids, flavonoids, and tannins (Krishnaveni and Mirunalini 2010).

Costus speciosus is among the most effective Islamic traditional medicinal plants (Emami et al., 2016). It has been proven in the authentic Hadith present in Sunan Abi Dawud, the Book of Medicine (Kitab Al-Tibb) in which Umm Qasis, the daughter of Mihsan said: I brought my son to the Messenger of Allah while I had compressed his uvula for its swelling. He said: Why do you afflict your children by squeezing for a swelling in the uvula? Apply this Indian aloeswood (costus), for it contains seven types of remedies (Khalifa and Al-Elyani 2012). Moreover, C. speciosus is an important medicinal plant which used widely for the treatment of various diseases which possesses multiple active constituents and has many pharmacological activities including antioxidant, 


\section{El-Sayed H. Bakr and Mona. E.M.Naga}

anti-inflammatory, steroidogenic, anticancer, antidiabetic,
hypolipidemic, hepatoprotective, adaptogenic, and antimicrobial
characteristics (El-Far et al., 2018). In vitro trials have stated the
antioxidant activity of C. speciosus methanolic, ethanolic, and
chloroform extracts of leaves, stem peel, peeled stem, and roots
assessed 2' azino bis 3 ethylbenzothiazoline 6 sulfonic acid, and
thiobarbituric acid (TBA) showing more hydroxyl radical scavenging
activity and free-radical quenching ability (Vijayalakshmi and Sarada 2008). Furthermore, phytochemical composition of costus speciosus showed the presence of saponins, alkaloids, tannins, flavonoids, and phenols in the aqueous stem extract, moreover, it could serve as source of bioactive compounds for therapeutic purposes and nutrition (Ukpabi et al., 2012).

Accordingly, this investigation aimed to study the immunomodulatory efficacy of phyllanthus emblica and costus speciosus aqueous extracts for immunosuppressive rats.

\section{Materials and Method}

\section{Materials}

\section{Experimental rats}

Forty-two (42) Sprague - Dawley male albino rats weighing 150-200 $\mathrm{g}$ b.wt., used in this investigation, obtained from Animal House of Ophthalmology Hospital, Giza, Egypt.

\section{Basal diet}

Basal diet consisted of casein (12.5\%), corn oil (10\%), vitamins mixture $(1 \%) 13$, cellulose $(5 \%)$, salt mixture $(4 \%)$, sucrose $(22 \%)$, choline chloride (0.2\%) and corn starch (up to 100\%) (Hegsted et al.,1941). 
Egyptian J. of Nutrition Vol. XXXV No. 2 (2020)

Phyllanthus emblica and costus speciosus

Phyllanthus emblica and costus speciosus were used as dry substances, obtained from Faculty of Agriculture, Damanhour University.

\section{Cyclophosphamide}

Cyclophosphamide was used as a dry substance purchased from AlGomhoria Company for Chemicals, Cairo, Egypt.

\section{Methods}

\section{Preparation of aqueous extracts}

One gram of powdered phyllanthus emblica or costus speciosus mixed with $100 \mathrm{ml}$ distilled water were boiled for $10 \mathrm{~min}$ then cooled for $15 \mathrm{~min}$., filtered then freeze-dried and the desired dose of aqueous extracts prepared as the method prescribed by (Lemhadri et al., 2004). The extracts were orally given to different groups at doses of 250 and $500 \mathrm{mg} / \mathrm{kg}$ body weight.

\section{Experimental design}

Forty-two (42) male albino rats divided to six equal groups ( $n=7$ rats) as follows: Group (1) was fed on the basal diet only during the whole experimental period as control negative group ( $\mathrm{C}-\mathrm{ve})$. The rest five groups were once injected intraperitoneally with a single dose (200 $\mathrm{mg} / \mathrm{kg}$ body weight) of cyclophosphamide as the method prescribed with Mythili et al., (2004), then divided into the following groups:

Group (2): Orally administered once by cyclophosphamide at a dose of $200 \mathrm{mg} / \mathrm{kg}$ b.wt., and fed on basal diet along the experimental period as $(\mathrm{C}+\mathrm{ve})$. 


\section{El-Sayed H. Bakr and Mona. E.M.Naga}

Group (3): Rats ingested by cyclophosphamide at a dose of $200 \mathrm{mg} / \mathrm{kg}$ b.wt., orally ingested with aqueous extract of phyllanthus emblica at a dose of $250 \mathrm{mg} / \mathrm{kg}$ b.wt., for 45 days.

Group (4): Rats ingested once by cyclophosphamide at a dose of $200 \mathrm{mg} / \mathrm{kg}$ b.wt., ingested with aqueous extract of phyllanthus emblica at a dose of $500 \mathrm{mg} / \mathrm{kg}$ b.wt., for 45 days.

Group (5): Rats ingested once by cyclophosphamide at a dose of $200 \mathrm{mg} / \mathrm{kg}$ b.wt., orally ingested with aqueous extract of costus speciosus at a dose of $250 \mathrm{mg} / \mathrm{kg}$ b.wt., for 45 days.

Group (6): Rats ingested once by cyclophosphamide at a dose of $200 \mathrm{mg} / \mathrm{kg}$ b.wt., orally ingested with aqueous extract of costus speciosus at a dose of $500 \mathrm{mg} / \mathrm{kg}$ b.wt., for 45 days.

\section{Biochemical Evaluation}

At the end of experimental period (45 days), blood samples were collected to determine the following parameters: CD4, CD8, CD16 and CD19 were analyzed by flow cytometric analysis as the methods prescribed by Adrienne et al., (2013). IgM and IgG were determined using indirect enzyme-linked immunosorbent assay (ELISA) for antibody detection as the methods described by Toledo et al. (2003). The levels of serum albumin and globulin were determined using a method of Doumas et al. (1971).

\section{Statistical Analyses}

Statistical analyses were performed by using SPSS (v.16, IBM SPSS Statistics, US) at $\mathrm{p} \leq 0.05$ by using the means and one-way ANOVA followed by low significant difference post hoc multiple comparisons (SPSS, 1998). 
Egyptian J. of Nutrition Vol. XXXV No. 2 (2020)

\section{Results and Discussion}

\section{Immunomodulatory efficacy for CD4 and CD8}

Results listed in table (1) display the immunomodulatory efficacy of Phyllanthus emblica and Costus speciosus aqueous extracts in immunosuppressive rats for CD4 and CD8 as types of leucocytes that play an important role in the immune system function by fighting infection which made in the bone marrow, and mature in the thymus gland which circulate throughout the body in the bloodstream, spleen and the lymph nodes.

It could be concluded from the results of the table that CD4 and Cd8 in control +ve intoxicated group were $225.00 \pm 7.73$ and $125.00 \pm 8.37$ Cells $/ \mu \mathrm{L}$ but in control -ve healthy group were $850.00 \pm 9.13$ and $550.00 \pm 7.51$ Cells $/ \mu \mathrm{L}$,. These results denote that there were significant decrease for CD4 and CD8 in control +ve intoxicated group (Immunosuppressive rats without treatment) as compared to control -ve healthy group (normal rats). All rats orally ingected with all experimental doses of Phyllanthus emblica and Costus speciosus aqueous extracts showed significant increases in CD4 and CD8 count when compared to control positive $(C+v e)$ group. The group orally administered with Costus speciosus at a dose of $500 / \mathrm{mg} / \mathrm{kg}$ showed the highest significant improvement not only in CD4 but also in CD8 when compared to all experimental groups.

These results confirmed by the results of Bhandari and Kamdod, (2012) who reported that Phyllanthus emblica Linn and its phytochemicals exhibit anticarcinogenic properties according their possession of radiomodulatory, antimutagenic, chemomodulatory, free radical scavenging, chemopreventive, antioxidant, 


\section{El-Sayed H. Bakr and Mona. E.M.Naga}

anti-inflammatory, and immunomodulatory activities. Furthermore, Charoenteeraboon et al., (2010) concluded that Phyllanthus emblica is a rich source of vitamin $\mathrm{C}$ and containing a mixture of phenolic compounds and a potential source of natural antioxidants, having free radical scavenging activity, acting as cyto-, hepato-, and radio-protection.

Moreover, Selim and Al-Jaouni (2016) recorded that Costus speciosus is a widely an important medicinal plant used in many indigenous medicinal formulations suggesting that diosgenin isolated from C. speciosus possess anticancer, apoptotic and inhibitory effects on cell proliferation. Furthermore, Kala et al., (2015) showed that $n$-butanolic fraction as a content of costus speciosus koen rhizome hydroalcoholic extract possessed immunostimulatory activity.

\section{Immunomodulatory efficacy for CD16 and CD19}

Table (2) results show the immunomodulatory efficacy of Phyllanthus emblica and Costus speciosus aqueous extracts in immunosuppressive rats for CD16 and CD19 as an important role in the immune system function. It is cleared from the data in the table that there were significant decrease in CD16 and CD19 in control +ve intoxicated group (Immunosuppressive rats without treatment) when compared to control -ve healthy group (normal rats) which the values of mean $\pm S E$ were $75.00 \pm 5.71$ and $345.00 \pm 9.20 \mathrm{Cells} / \mu \mathrm{L}$ for CD16, and $80.00 \pm 7.41$ and $300.00 \pm 5.29$ Cells $/ \mu \mathrm{L}$ for CD19, respectively. Intoxicated rats which orally ingested with Costus speciosus at a dose of $500 \mathrm{mg} / \mathrm{kg}$. b. wt., showed the highest significant improvement in CD16 and CD19 followed by Phyllanthus emblica at a dose of $500 / \mathrm{mg} / \mathrm{kg}$. b. wt., group, then Costus speciosus at a dose 


\section{Egyptian J. of Nutrition Vol. XXXV No. 2 (2020)}

of $250 \mathrm{mg} / \mathrm{kg}$. b. wt., group, and finally, phyllanthus emblica at a dose of $250 / \mathrm{mg} / \mathrm{kg}$. b. wt., group as compared to control positive groups.

These findings agreed the findings of Sai et al., (2002) who demonstrated that Phyllanthus emblica linn relieved the immunosuppressive effects of chromium on lymphocyte proliferation and restored gamma interferon production considerably. Also, Pandey (2011) revealed that Phyllanthus emblica possess the ability to inhibit mutations in genes and repairs the chromosomal abnormalities related to the presence of ellagic acid which act as a powerful antioxidant. Furthermore, Ngamkitidechakul et al., (2010) suggested that Phyllanthus emblica Linn exhibits anticancer activity against selected cancer cells, suggesting further study as a possible chemopreventive agent.

Morover, Chandra et al., (2015) studied the immunostimulatory activity of Costus speciosus referring to the mechanism of immune stimulatory action of saponins found in it, reporting that saponins induced the production of cytokines as to interleukins and interferons that might stimulate the immune stimulant action.

\section{Immunomodulatory efficacy for IgM and IgG}

Data present in table (3) show the immunomodulatory efficacy of Phyllanthus emblica and Costus speciosus aqueous extracts in immunosuppressive rats for immunoglobulin $M$ (IgM) which found mainly in blood and lymph fluid and the first antibody the body makes when fights a new infection, and immunoglobulin $\mathrm{M}$ (IgM) the most common antibody in the blood and other body fluids which protects against bacterial and viral infections. 


\section{El-Sayed H. Bakr and Mona. E.M.Naga}

It could be noticed from the results in the table that the mean $\pm S E$ levels of $\operatorname{lgM}$ and $\operatorname{lgG}$ in control positive intoxicated group $(\mathrm{C}+\mathrm{ve})$ were $7.52 \pm 0.42$ and $1.55 \pm 0.05$ compared to $14.20 \pm 0.19$ and $5.27 \pm 0.02 \mathrm{mg} / \mathrm{dl}$ in normal healthy control rats (C -ve), respectively.

These results showed that there were significant decrease in the levels of $\operatorname{lgM}$ and $\lg G$ in control positive intoxicated group as compared to normal healthy rats. All rats injected intraperitoneal with a single dose (200 mg/kg body weight) of cyclophosphamide for immunosuppression then orally administered with Phyllanthus emblica and Costus speciosus aqueous extracts at all tested doses showed significant improvements in the levels of $\lg M$ and $\lg G$ as compared to control positive intoxicated groups. Rats orally ingested with Costus speciosus at a dose of $500 / \mathrm{mg} / \mathrm{kg}$. b. wt., showed the highest significant improvements in the levels of IgM and IgG when compared to all experimental groups.

These results are in agreement with the results of Luo et al., (2011) who demonstrated that phenolics found in Phyllanthus emblica had active radical scavenging and strong inhibition ability of lipid peroxidation. Also, Verma and Verma, (2010) mentioned that Phyllanthus emblica Linn contains vitamin C which act as an effective antioxidant constituent.

Moreover, Chandra et al., (2015) estimated the serum immunoglobulins (Ig) level and phagocytic index as a model for evaluation of immunomodulatory activity, suggesting that both low and high doses (100 and $200 \mathrm{mg} / \mathrm{kg}$ b. wt.) of Costus speciosus koen rhizome extract elevated serum immunoglobulin G (lgG) level and phagocytic index, moreover, the effect at higher dose was highly significant than lower dose. Furthermore, Ilango et al., (2020) 
Egyptian J. of Nutrition Vol. XXXV No. 2 (2020)

demonstrated that ethanolic extract of Costus speciosus rhizome possesses potential to prevent noise stress induced changes in rodent immune system as soon as a strong applicable immunomodulatory prospective to clinical practices.

\section{Immunomodulatory efficacy for albumin and globulin}

The immunomodulatory efficacy of orally ingestion with Phyllanthus emblica and Costus speciosus aqueous extracts for albumin and globulin in immunosuppressive rats is recorded in table (4).It could be observed from the results in the previous table that the means $\pm S E$ for albumin and globulin in control +ve intoxicated groups were $1.55 \pm 0.09$ and $0.94 \pm 0.04 \mathrm{mg} / \mathrm{dl}$ but in control -ve healthy group were $4.11 \pm 0.05$ and $3.21 \pm 0.02 \mathrm{mg} / \mathrm{dl}$, respectively.

These results revealed that there were significant decreases in albumin and globulin in control +ve intoxicated group (immunosuppressive rats without treatment) as compared to control ve healthy group (normal rats). All rats orally administered with all experimental doses of Phyllanthus emblica and Costus speciosus aqueous extracts showed significant increase in albumin and globulin when compared to control positive $(\mathrm{C}+\mathrm{ve})$ intoxicated group. The group orally ingested with Costus speciosus at a dose of 500/mg/kg b. wt., showed the highest significant improvents in the level of albumin and globulin when compared to all experimental groups. At the same time, there were no significant differences occurred among the groups orally administered with Costus speciosus at a dose of 250/mg/kg b. wt., and Phyllanthus emblica at doses of 250 and 500 $\mathrm{mg} / \mathrm{kg} \mathrm{b.} \mathrm{wt.}$

Data agreed with the findings of Suresh and Vasudevan (1994) who reported that Phyllanthus emblica, an excellent source of 


\section{El-Sayed H. Bakr and Mona. E.M.Naga}

vitamin C (ascorbate), improved natural killer (NK) cell activity and antibody dependent cellular cytotoxicity. Moreover, Lue et al (2011) and Nuzul et al., (2020) clearly showed the presence of fatty acids in Phyllanthus emblica which play a main role in traditional medicines efficacy particularly as antioxidant and antimalarial.

Meanwhile, Pawar and Pawar (2012) concluded that Costus speciosus contains an important medicinal and ornamental properties used to cure different diseases by possessing many pharmacological activities such as antibacterial, antifungal, anticholineesterase, antioxidant, antihyperglycemic, antiinflammatory, antidiuretic, larvicidal, analgesic, antipyretic, antistress and estrogenic activity. Furthermore, Jayasri, et al., (2009) evaluated the antioxidant activity of the plant Costus speciosus suggesting that this plant can be used as a potent source of natural antioxidants.

\section{Conclusion}

The present investigation revealed that Phyllanthus emblica and Costus speciosus aqueous extracts possess immunomodulatory efficacy with regard to immunosuppressive rats. 
Egyptian J. of Nutrition Vol. XXXV No. 2 (2020)

Table (1): Immunomodulatory efficacy of Phyllanthus emblica and Costus speciosus aqueous extracts in immunosuppressive rats for CD4 and CD8.

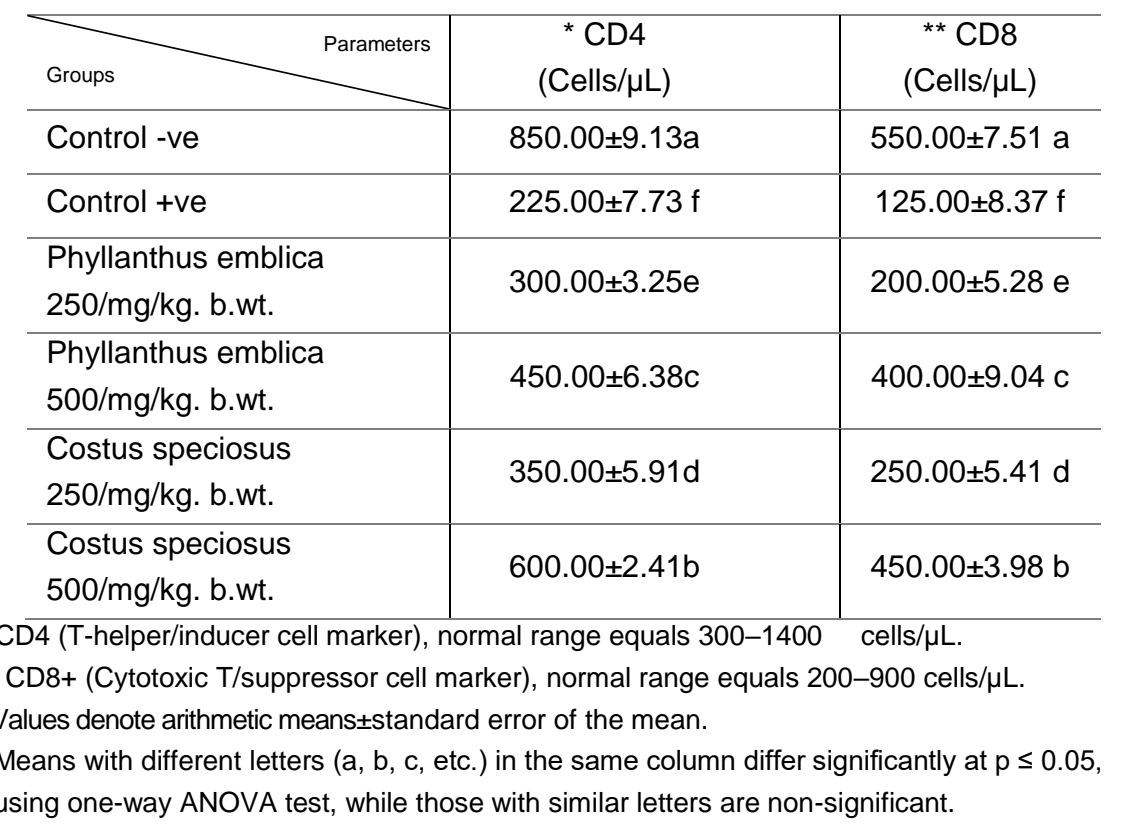




\section{El-Sayed H. Bakr and Mona. E.M.Naga}

Table (2): Immunomodulatory efficacy of Phyllanthus emblica and Costus speciosus aqueous extracts in immunosuppressive rats for CD16 and CD19.

\begin{tabular}{|c|c|c|}
\hline Groups & $\begin{array}{c}{ }^{*} \text { CD16 } \\
(\text { Cells } / \mu \mathrm{L})\end{array}$ & 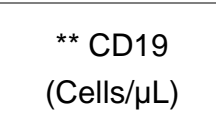 \\
\hline Control -ve & $345.00 \pm 9.20 \mathrm{a}$ & $300.00 \pm 5.29 a$ \\
\hline Control +ve & $75.00 \pm 5.71 \mathrm{f}$ & $80.00 \pm 7.41 \mathrm{f}$ \\
\hline $\begin{array}{l}\text { Phyllanthus emblica } \\
250 \mathrm{mg} / \mathrm{kg} \text {. b.wt. }\end{array}$ & $125.00 \pm 8.28 \mathrm{e}$ & $105.00 \pm 3.05 \mathrm{e}$ \\
\hline $\begin{array}{l}\text { Phyllanthus emblica } \\
500 \mathrm{mg} / \mathrm{kg} \text {. b.wt. }\end{array}$ & $205.00 \pm 3.39 c$ & $195.00 \pm 2.28 \mathrm{c}$ \\
\hline $\begin{array}{l}\text { Costus speciosus } \\
250 \mathrm{mg} / \mathrm{kg} \text {. b.wt. }\end{array}$ & $165.00 \pm 7.04 \mathrm{~d}$ & $125.00 \pm 4.33 \mathrm{~d}$ \\
\hline $\begin{array}{l}\text { Costus speciosus } \\
500 \mathrm{mg} / \mathrm{kg} \text {. b.wt. }\end{array}$ & $295.00 \pm 2.49 \mathrm{~b}$ & $250.00 \pm 8.32 b$ \\
\hline
\end{tabular}

${ }^{*} \mathrm{CD} 16$ (natural killer cell marker), normal range equals

90-600 cells/ $\mu \mathrm{L}$.

${ }^{* *} \mathrm{CD} 19$ (mature B cell marker), normal range equals 100

500 cells $/ \mu \mathrm{L}$.

- Values denote arithmetic means \pm standard error of the mean.

- Means with different letters (a, b, c, etc.) in the same

column differ significantly at $p \leq 0.05$,

using one-way ANOVA test, while those with similar

letters are non-significant. 
Egyptian J. of Nutrition Vol. XXXV No. 2 (2020)

Table (3): Immunomodulatory efficacy of Phyllanthus emblica and Costus speciosus aqueous extracts in immunosuppressive rats for $\lg M$ and $\lg G$.

\begin{tabular}{l|c|c}
\hline \multicolumn{1}{|c|}{ Parameters } & $\begin{array}{c}\operatorname{lgM} \\
(\mathrm{mg} / \mathrm{dl})\end{array}$ & $\begin{array}{c}\mathrm{IgG} \\
(\mathrm{mg} / \mathrm{dl})\end{array}$ \\
\hline Control -ve & $14.20 \pm 0.19 \mathrm{a}$ & $5.27 \pm 0.02 \mathrm{a}$ \\
\hline Control+ve & $7.52 \pm 0.42 \mathrm{f}$ & $1.55 \pm 0.05 \mathrm{f}$ \\
\hline $\begin{array}{l}\text { Phyllanthus emblica } \\
250 \mathrm{mg} / \mathrm{kg} \text {. b.wt. }\end{array}$ & $8.50 \pm 0.22 \mathrm{e}$ & $2.09 \pm 0.07 \mathrm{e}$ \\
\hline $\begin{array}{l}\text { Phyllanthus emblica } \\
500 \mathrm{mg} / \mathrm{kg} . \text { b.wt. }\end{array}$ & $9.30 \pm 0.37 \mathrm{~d}$ & $2.29 \pm 0.01 \mathrm{~d}$ \\
\hline $\begin{array}{l}\text { Costus speciosus } \\
250 \mathrm{mg} / \mathrm{kg} \text {. b.wt. }\end{array}$ & $11.53 \pm 0.06 \mathrm{c}$ & $3.03 \pm 0.03 \mathrm{c}$ \\
\hline $\begin{array}{l}\text { Costus speciosus } \\
500 \mathrm{mg} / \mathrm{kg} \text {. b.wt. }\end{array}$ & $12.74 \pm 2.11 \mathrm{~b}$ & $3.41 \pm 0.06 \mathrm{~b}$ \\
\hline
\end{tabular}

- Values denote arithmetic means \pm standard error of the mean.

- Means with different letters ( $a, b, c$, etc.) in the same column differ significantly at $p \leq 0.05$,

using one-way ANOVA test, while those with similar letters are non-significant. 


\section{El-Sayed H. Bakr and Mona. E.M.Naga}

Table (4): Immunomodulatory efficacy of Phyllanthus emblica and Costus speciosus aqueous extracts in immunosuppressive rats for albumin and globulin.

\begin{tabular}{l|c|c}
\hline \multicolumn{1}{c|}{ parameters } & $\begin{array}{c}\text { Albumin } \\
(\mathrm{mg} / \mathrm{dl})\end{array}$ & $\begin{array}{c}\text { Globulin } \\
(\mathrm{mg} / \mathrm{dl})\end{array}$ \\
\hline Control -ve & $4.11 \pm 0.05 \mathrm{a}$ & $3.21 \pm 0.02 \mathrm{a}$ \\
\hline Control +ve & $1.55 \pm 0.09 \mathrm{e}$ & $0.94 \pm 0.04 \mathrm{e}$ \\
\hline Phyllanthus emblica & $2.71 \pm 0.05 \mathrm{~d}$ & $1.19 \pm 0.03 \mathrm{~d}$ \\
$250 \mathrm{mg} / \mathrm{kg}$. b.wt. & $2.89 \pm 0.06 \mathrm{~cd}$ & $1.25 \pm 0.05 \mathrm{~cd}$ \\
\hline $\begin{array}{l}\text { Phyllanthus emblica } \\
500 \mathrm{mg} / \mathrm{kg} . \text { b.wt. }\end{array}$ & $3.01 \pm 0.01 \mathrm{c}$ & $1.33 \pm 0.04 \mathrm{c}$ \\
\hline $\begin{array}{l}\text { Costus speciosus } \\
250 \mathrm{mg} / \mathrm{kg} . \text { b.wt. }\end{array}$ & $3.56 \pm 0.03 \mathrm{~b}$ & $2.41 \pm 0.03 \mathrm{~b}$ \\
\hline $\begin{array}{l}\text { Costus speciosus } \\
500 \mathrm{mg} / \mathrm{kg} . \text { b.wt. }\end{array}$ & & \\
\hline
\end{tabular}

- Values denote arithmetic means \pm standard error of the mean.

- Means with different letters (a, b, c, etc.) in the same column differ significantly at $p \leq 0.05$,

using one-way ANOVA test, while those with similar letters are non-significant. 
Egyptian J. of Nutrition Vol. XXXV No. 2 (2020)

\section{References}

Adrienne, L. E.; Sarah, P. G.; Geoffrey, C. C.; Matthew, W. H.; Mark, S.; Christopher, M. F.; Bridget, A. R.; Richard, W. T. and Lutz, E. B. (2013):

Professional killer cell deficiencies and decreased survival in pulmonary arterial hypertension. J. of Asian Pacific SOC.Respirol. 18: 1271-1277.

Bhandari, P. R. and Kamdod, M. A. (2012):

Emblica officinalis (Amla): A review of potential therapeutic applications. Int. J. Green Pharm., 6:257-269.

Chandra, K.; Syed, S. A. and Najam, A. K. (2015):

Immunostimulatory potential of $n$-butanolic fraction of hydroalcoholic extract of costus speciosus koen rhizome. Int $\mathrm{J}$ Pharmac Sc. Res (IJPSR), 6(7): 2886-2892.

Chaplin, D. D. (2010):

Overview of the Immune Response. J. Allergy Clin. Immunol., 125(2 Suppl 2): S3-23.

Charoenteeraboon, J. Ngamkitidechakul, C.; Soonthornchareonnon, N.; Jaijoy, K. and Sireeratawong, S. (2010):

Antioxidant activities of the standardized water extract from fruit of Phyllanthus emblica Linn. J. of SC. Technol. 32(6):599-604. 


\section{El-Sayed H. Bakr and Mona. E.M.Naga}

Childs, C. E.; Calder, P. C. and Miles, E. A. (2019):

Diet and Immune Function. J. Nutrients, 11(8): 1933.

Dai, X.; Cheng, H.; Bai, Z. and Li, J. (2017):

Breast cancer cell line classification and its relevance with breast tumor subtyping. J Cancer, 8(16): 3131-3141.

Doumas, B.; Watson, W. and Biggs, H. (1971):

Albumin standards and the measurement of serum albumin with bromocresol green. Clinica Chimica Acta, 31: 87-96.

El-Far, A.; Shaheen, H.; Alsenosy, A.; El-Sayed, Y.; Al-Jaouni, S. K. and Mousa, S. (2018):

Costus speciosus: Traditional Uses, Phytochemistry, and Therapeutic Potentials. J. Pharmacognosy Rev. 12(23):120127.

Emami, S. A.; Sahebkar, A. and Javadi, B. (2016):

Paresthesia: A Review of its definition, etiology and treatments in view of the traditional medicine. J. Curr. Pharm. Des., 22:321-327.

Hegsted, D.; Mills, R. and Perkins, E. (1941):

Salt mixture. J. Biol. Chem., 138: 459.

llango, S.; Saikumar, P.; Sembulingam, K. and Jayakumar, S. (2020):

Antistressor effect of Costus Speciosus on noise induced immunological changes in rats. Int. J Res. Pharmac. Sci, 11(3):2973-2978. 
Egyptian J. of Nutrition Vol. XXXV No. 2 (2020)

Jayasri, M. A.; Lazar M. and Radha, A. (2009):

A report on the antioxidant activity of leaves and rhizomes of Costus pictus D. Don. Int. J Integrative Biol. 5(1):20-26.

Kala, C.; Ali, S. S. and Khan, N. A. (2015

mmunostimulatory potential of N-Butanolic fraction of hydroalcoholic extract of Costus speciosus koen rhizome. Int. J Pharmac. Sci. Res. (IJPSR), 6(7): 2886-2892.

Khalifa, S. A. and Al-Elyani, R. A. (2012):

Histological and ultrastructural studies on the effect of Costus plant and amphotericin $B$ on male lung rats infected by Aspergillus niger-semantic scholar. Life Sci. J., 9:5321:5338.

Krishnaveni, M. and Mirunalini, S.(2010):

Therapeutic potential of Phyllanthus emblica (Amla): the ayurvedic wonder. J. Basic Clin. Physiol Pharmacol., 21(1):93-105.

Lemhadri, A.; Zeggwagh, N. A.; Maghrani, M.; Jouad, H. and Eddouks, M. (2004):

Inhibition of endogenous glucose production accounts for hypoglycaemic effect of Spergularia purpurea in diabetic mice. J. Ethnopharmacol, 92(2-3): 251-256.

Luo, W.; Zhao, M.; Yang, B.; Ren, J.; Shen, G. and Rao, G. (2011): Antioxidant and antiproliferative capacities of phenolics purified from Phyllanthus emblica L. Food. 126: 1, 277-282. 


\section{El-Sayed H. Bakr and Mona. E.M.Naga}

Mythili, Y.; Sudharsan, P.T.; Selva-kumar, E. and Varalakshmi, P. (2004):

Protective effect of DL- $\alpha$-lipoic acid on cyclophosphamide induced oxidative cardiac injury. J. Chemico-Biologi-cal Interactions.,151(1): 13-19.

Ngamkitidechakul, $\quad$ C.; Jaijoy, K.; Hansakul, P.; Soonthornchareonnon, N. and Sireeratawong, S. (2010): Antitumour effects of Phyllanthus emblica L.: Induction of cancer cell apoptosis and inhibition of in vivo tumour promotion and in vitro invasion of human cancer cells. Phytother., Res., 24:1405-1413.

Nuzul, A.; Yudha, F.; Mahdi, A. and Rinidar, R. (2020):

Chemical Compounds of Malacca Leaf (Phyllanthus emblica) after Triple Extraction with N-Hexane, Ethyl Acetate, and Ethanol. Hindawi, Scientific World Journal, Volume 2020, Article ID 2739056, 5 pages. DOI. 10.1155/2020/2739056

Pandey, G. (2011):

Some important anticancer herbs: A review. Int. Res. J. Pharm., 2(7):45-52.

Pawar, V. A. and Pawar, P. R. (2012):

Costus speciosus: An Important Medicinal Plant. Int.J. Sci. Res. (IJSR), (3): 7 
Egyptian J. of Nutrition Vol. XXXV No. 2 (2020)

Sai, R. M.; Neetu, D.; Yogesh, B.; Anju, B.; Dipti, P. and Pauline, T. (2002):

Cyto-protective and immunomodulating properties of Amla (Emblica officinalis) on lymphocytes: An in vitro study. J. Ethnopharmacol. 81(1):5-10.

Selim, S. and Al-Jaouni, S. (2016):

Anti-inflammatory, antioxidant and antiangiogenic activities of diosgenin isolated from traditional medicinal plant, Costus speciosus (Koen ex.Retz.) Sm. Journal of Natural Product Research, (30): 16.

SPSS, (1998):

Statistical Package for Social Science, Computer Software, Ver.16, 1998, SPSS Company, London, UK.

Suresh, K. and Vasudevan, D. M. (1994):

Augmentation of murine natural killer cell and antibody dependent cellular cytotoxicity activities by Phyllanthus emblica, a new immunomodulator. J. Ethnopharmacol., 44:5560

Toledo, R., Espert, A., Muñoz-Antoli, C., Marcilla, A., Fried, B., and Esteban, J. G., (2003):

Development of an antibody-based capture enzyme-linked immunosorbent assay for detecting Echinostoma caproni (Trematoda) in experimentally infected rats: kinetics of coproantigen excretion. J. Parasitolo. 89: 1227-1231. 


\section{El-Sayed H. Bakr and Mona. E.M.Naga}

Ukpabi C. F., Agbafor K. N., Ndukwe O. K., Agwu, A. and Nwachukwu, S. N., (2012):

"Phytochemical Composition of Costus Afer Extract and Its Alleviation of Carbon Tetrachloride - induced Hepatic Oxidative Stress and Toxicity", Int.J. Modern Botany, 2(5):120-126.

Verma, K. C. and Verma, S. K. (2010):

Analysis of active ingredients and SDS-PAGE profiling of Amla (Phyllanthus emblica L.). Agricultural Science Digest, 30(1): 29-31.

Vijayalakshmi, M. A. and Sarada, N. C. (2008):

Screening of Costus speciosus extracts for antioxidant activity. J. Fitoterapia, 79:197-198. 
Egyptian J. of Nutrition Vol. XXXV No. 2 (2020)

الفعالية المناعية للمستخلصات المائية للأملج والقسط الهندي لاى الفئران المثبطة مناعيا

\author{
السيا حامد علي بكر' منى ابراهيم محمد نجا' \\ ' قسم التغذية و علوم الأطعمة ـ كلية الاقتصاد المنزلي - جامعة المنوفية ـ شبين الكوم

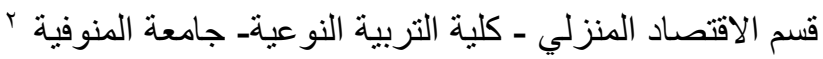

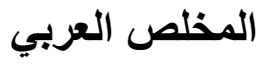

يساعد الجهاز الهناعي على التخلص من المواد السامة أو الدسبية للحساسية التي تخترق

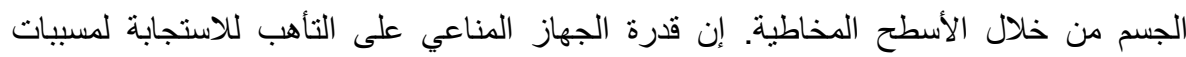

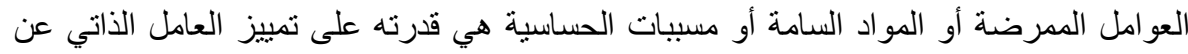

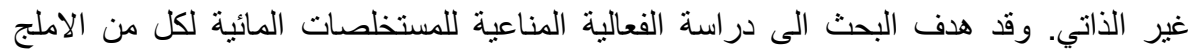

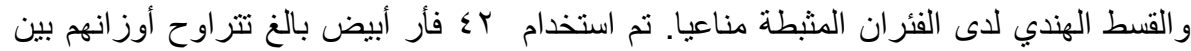

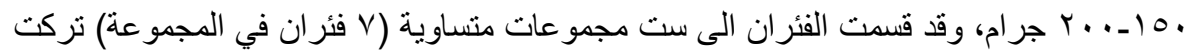

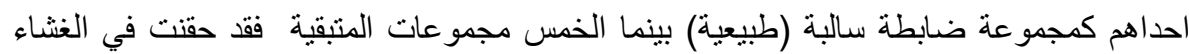

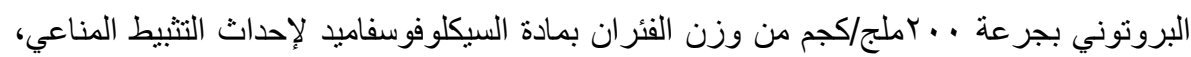

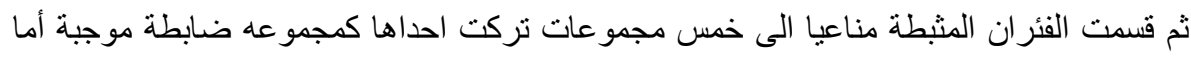

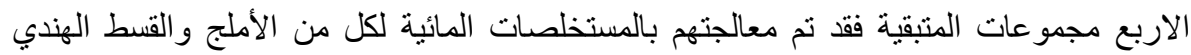

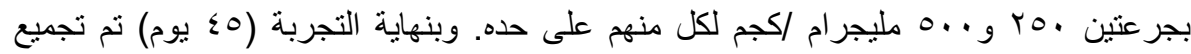
عينات الدم وقياس CD4, CD8, CD16, CD19, IgM and IgA علاوة على ذللك قياس مستوى الألبومين و الجلوبيولين. وقد خلصت النتائج الى أن الأملج و القسط الهندي يعززان القان القدرة

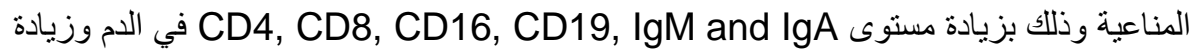

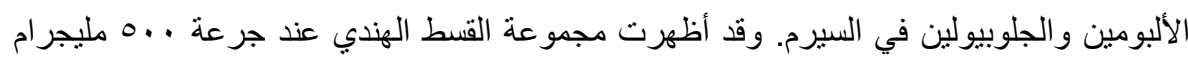

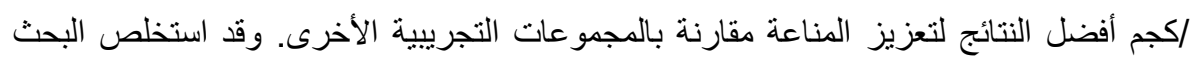

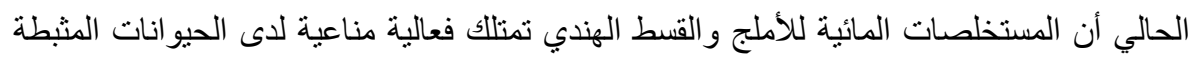

